\title{
A genealogia e a ética foucaultianas nos estudos discursivos
}

Foucaultian genealogy and ethics in discursive studies

\author{
Kátia Menezes de Sousa ${ }^{1}$ \\ Universidade Federal de Goiás - UFG \\ Universidade Federal de Uberlândia - UFU
}

\begin{abstract}
RESUMO: Michel Foucault, em seus últimos trabalhos, dedica-se à investigação da relação do sujeito com a verdade, sendo a sexualidade um domínio entre outros. O objetivo central deste artigo é mostrar como Foucault chega ao entendimento da ética como resultado da relação do sujeito consigo mesmo, em que ele se constitui como sujeito moral de suas próprias ações. Seguindo sua genealogia para estudar a ética, este texto é organizado em três partes para tratar, primeiro, dos deslocamentos teóricos efetuados por Foucault, depois para discutir a relação do discurso com a constituição de um sujeito ético, e, por último, para pensar a constituição dos modos de ser do sujeito a partir das práticas de si. As considerações finais sugerem uma reflexão acerca da estética da existência nos jogos de verdade. As reflexões propostas visam a contribuir tanto para a compreensão das formas históricas da obrigação e da possibilidade de dizer-averdade, quanto para pensar em formas de resistência que possam considerar as práticas de si e o dizer-a-verdade como procedimentos éticos imprescindíveis para ser governado, governar-se a si mesmo e aos outros.
\end{abstract}

Palavras-chave: Discurso; Verdade; Subjetividade; Ética; Estética.

ABSTRACT: Michel Foucault, in his last works, realizes investigations about the relation of the subject with the truth, considering the sexuality as one space between others. The central aim of this article is to show how Foucault comes to the understanding of ethics as a result of the subject's interaction with himself, in which he constitutes himself as a moral subject of his own actions. Following its genealogy to study the ethics, this text is organized in three parts, to deal, firstly, with the theoretical displacements effected by Foucault; later to discuss the relation between discourse and the constitution of an ethical subject; finally, to think the forms of constitution of being of the subject based on the practices of self. The final considerations suggest a reflection on the aesthetics of existence in the exercises of truth. These reflections aim to contribute both to understanding the historical forms of obligation and the possibility of telling the truth, and to considering forms of resistance that could take self-practices and truth-telling as essential ethical procedures for to be governed, to govern oneself and others.

Keywords: Discourse; Truth; Subjectivity; Ethic; Aesthetics.

\footnotetext{
${ }^{1}$ Líder do TRAMA - Laboratório de Pesquisas e Estudos Discursivos.
} 


\section{Considerações iniciais}

Nos dias de hoje, um exercício de reflexão sobre a ética nos é fortemente solicitado. Contudo, já temos comprovado que as prescrições de maneiras de fazer e de dizer não são garantia de transformação do indivíduo em um sujeito ético. Essa constatação corrobora o pensamento de Michel Foucault sobre a ética, depois de haver estudado a relação do sujeito com a verdade, estudo que se dará a partir do curso ministrado em 1980, Do governo dos vivos. Na introdução do livro História da sexualidade 2 - o uso dos prazeres, Foucault antecipa que a história do cristianismo ou da Europa moderna nos leva a pensar que "lá onde as proibições são mais fundamentais, lá onde as obrigações são mais coercitivas é que, de uma forma geral, as morais desenvolvem as mais insistentes exigências de austeridade [...] Entretanto, parece que tal não foi o caso na Antiguidade" (FOUCAULT, 1984, p. 24). Seu projeto, desenvolvido na História da sexualidade 2 e 3, era o de perceber de que maneira, nas sociedades ocidentais modernas, “constitui-se uma 'experiência' tal, que os indivíduos são levados a reconhecer-se como sujeitos de uma 'sexualidade' que abre campos de conhecimentos bastante diversos, e que se articula num sistema de regras e coerções" (FOUCULT, 1984, p. 10). Logo, como seus projetos anteriores, o objetivo era o de compreender os acontecimentos que levaram o indivíduo moderno a se constituir e se reconhecer como sujeito do que faz, pensa e diz.

Numa primeira versão do prefácio à História da sexualidade 2, Foucault (2014a) explica que, para analisar as formas de relação consigo em períodos em que os sistemas normativos eram menores e para poder separar as formas de relação consigo diferentes das que caracterizam a experiência da sexualidade moderna, ele foi levado a retroceder no tempo cada vez mais distante do quadro cronológico que fixara. Na entrevista intitulada "Sobre a genealogia da ética: um resumo do trabalho em curso" (FOUCAULT, 2014b, p. 215), ele justifica a problematização da atividade sexual no pensamento grego clássico e romano imperial pela maneira diferente como eles integravam as proibições em uma relação consigo, em que a moral era de ordem estética, um problema de escolha pessoal, e assevera: "eu não acredito que se possa encontrar nenhum traço do que se poderia chamar de 'normalização', por exemplo, na moral filosófica dos antigos”.

Tanto no curso de 1981, Subjetividade e verdade, quanto no curso de 1982, A Hermenêutica do sujeito, Foucault lembra seu interlocutor que daquele momento em diante o eixo geral de sua pesquisa seria a relação do sujeito com a verdade, sendo a sexualidade um 
domínio entre outros. Gros (2006, p. 621), em texto sobre a situação do curso A hermenêutica do sujeito, comenta que

[...] a partir dos anos oitenta, estudando as técnicas de existência promovidas pela Antiguidade grega e romana, Foucault deixa aparecer uma outra figura do sujeito, não mais constituído, mas constituindo-se através de práticas regradas. O estudo do Ocidente moderno lhe ocultara por muito tempo a existência destas técnicas, obscurecidas que estavam no interior do arquivo pelos sistemas de saber e os dispositivos de poder.

Essa preocupação com a relação entre sujeito e verdade vai constituir o terceiro domínio de suas pesquisas que se devolveram em torno das relações acerca do domínio sobre as coisas, o das relações de ação sobre os outros e o das relações consigo mesmo. Foucault (2000a) adverte que passar pelos três eixos, o do saber, o do poder e o da ética, não significa que os três domínios sejam estranhos uns aos outros.

Nesse sentido, o objetivo central deste artigo é percorrer os últimos escritos de Michel Foucault para mostrar como ele vai chegar ao entendimento da ética como resultado da relação do sujeito consigo mesmo, relação esta que é capaz de determinar como o indivíduo deve constituir-se como sujeito moral de suas próprias ações. Sobre este ponto, Foucault (2014b, p. 224) assinala que é necessário fazer uma distinção entre o código moral e os atos ou condutas, pois estes últimos "são a atitude real das pessoas em face das prescrições morais que lhes são impostas". A ética atua também onde a moral não alcança. E Foucault (1984, p. 29) chama de história da ética,

[...] a história da maneira pela qual os indivíduos são chamados a se constituir como sujeitos de conduta moral; essa história será aquela dos modelos propostos para a instauração e o desenvolvimento das relações para consigo, para a reflexão sobre si, para o conhecimento, o exame, a decifração de si por si mesmo, as transformações que se procura efetuar sobre si.

Para isso, o autor propõe uma abordagem genealógica e evita os tratamentos do código moral, que normalmente atuam entre a obrigação e a proibição moral. Considerando a explicação de Foucault sobre sua opção pela problematização e pelo recuo às práticas gregas e romanas, Candiotto (2013a) resume o viés foucaultiano de análise da ética, argumentando que, se as condutas forem analisadas fora da perspectiva da proibição dos códigos de comportamento moral, mas pela problematização dos modos de "conduzir-se" diante deles, sua atuação estende-se à moral ocidental, do pensamento grego clássico até a modernidade, passando pela filosofia greco-romana e pelo cristianismo. 
Com base na ideia de modos de problematização das condutas, as considerações em torno da constituição ética do sujeito neste trabalho, inevitavelmente, se encontrarão às voltas com o fazer genealógico empreendido por Foucault, dada a sua preocupação com questões que foram por ele mesmo sistematizadas da seguinte forma: "como nos constituímos como sujeitos de nosso saber; como nos constituímos como sujeitos que exercem ou sofrem relações de poder; como nos constituímos como sujeitos morais de nossas ações" (FOUCAULT, 2000a, p. 350). Para ele, “o estudo (dos modos) de problematizações [...] é, portanto, a maneira de analisar, em sua forma historicamente singular, as questões de alcance geral" (FOUCAULT, 2000a, p. 350-351).

Em História da sexualidade II e III, portanto, Foucault empreenderá a dimensão genealógica, analisando a formação dos modos de problematização a partir das práticas e de suas modificações. Trata-se de um domínio da genealogia que constitui "uma ontologia histórica de nossas relações com a moral, que nos permite constituir-nos como agentes éticos" (FOUCAULT, 2014b). Em texto de 1971, Foucault explicou a genealogia que empreendia em seus trabalhos acerca da relação saber-poder, mas que pode ser estendida para a questão da ética, demonstrando que a genealogia deve ser a história das interpretações: "história das morais, dos ideais, dos conceitos metafísicos, história do conceito de liberdade ou da vida ascética, como emergências de diferentes interpretações" (FOUCAULT, 2000b, p. 270).

Apesar de Foucault ter descoberto na história da sexualidade uma genealogia do sujeito moderno, nos cursos dos anos de 1980, conforme Gros (2006), Foucault abandona o tema da sexualidade como referência básica privilegiada e se interessa mais pelos processos de subjetivação, considerados em e por eles mesmos. Na primeira aula de A hermenêutica do sujeito, Foucault (2006, p. 4) declara que gostaria de abordar naquele ano a seguinte questão: "em que forma de história foram tramadas, no Ocidente, as relações, que não estão suscitadas pela prática ou pela análise histórica habitual, entre estes dois elementos, o 'sujeito' e a "verdade"”. E anuncia que vai tomar como ponto de partida a noção de "cuidado de si". No curso do ano anterior, Subjetividade e verdade, dizendo do fato incontestável de que, numa sociedade como a nossa, há certos discursos que são, institucionalmente ou por consenso, reconhecidos como verdadeiros a partir do sujeito, Foucault (2016, p. 12) coloca o seguinte problema: "a partir do momento em que, numa cultura, há um discurso verdadeiro sobre o sujeito, que experiência o sujeito faz de si mesmo e que relação o sujeito tem a respeito de si mesmo em função dessa existência de fato de um discurso verdadeiro sobre ele?"

Seguindo sua genealogia para estudar a ética, este texto será organizado em três partes para tratar, primeiro, dos deslocamentos teóricos efetuados por Foucault, depois para discutir 
a relação do discurso com a constituição de um sujeito ético e, por último, para pensar a constituição dos modos de ser do sujeito a partir das práticas de si. Para fechar a discussão acerca da genealogia da ética, as considerações finais sugerem uma reflexão acerca da estética da existência nos jogos de verdade, considerando a parresía cínica na exposição de Foucault em A coragem da verdade, quando ele demonstra como o cinismo foi uma forma na qual modo de vida e dizer-a-verdade estavam diretamente ligados um ao outro. A estética da existência, conforme Foucault (2011, p. 141), constitui um aspecto da história da subjetividade que, "na medida em que constitui a vida como objeto para uma forma estética, foi por muito tempo encoberto e dominado, claro, pelo que poderíamos chamar de história da metafísica, história da psykhé, história da maneira como se fundou e estabeleceu a ontologia da alma".

A discussão que aqui será empreendida constitui parte do arcabouço teórico com o qual a Análise do Discurso de base foucaultiana, ou mesmo as outras análises do discurso, se valem para tratar das relações do sujeito com o dizer, com suas práticas sociais, com a verdade e consigo mesmo. Portanto, este texto visa a contribuir tanto para a compreensão das formas históricas da obrigação e da possibilidade de dizer-a-verdade, quanto para pensar em formas de resistência que possam considerar as práticas de si e o dizer-a-verdade como procedimentos éticos imprescindíveis para ser governado, governar-se a si mesmo e aos outros.

\section{Deslocamentos em torno do eixo saber-poder-sujeito}

Michel Foucault, em prefácio que abriria o segundo volume de História da sexualidade, mas que foi por ele descartado e, mais tarde, publicado no volume 9 da coleção Ditos e Escritos, explica que seu propósito era analisar a história da sexualidade como uma forma de experiência historicamente singular, procurando compreender

[...] como se constituiu nas sociedades ocidentais modernas, a partir e a propósito de certos comportamentos, uma experiência complexa em que se liga um campo de conhecimento (com conceitos, teorias, disciplinas diversas), um conjunto de regras (que distinguem o permitido e o proibido, o natural e o monstruoso, o normal e o patológico, o decente e o que não o é etc.), um modo de relação do indivíduo consigo mesmo (pelo qual ele pode reconhecer-se como sujeito sexual no meio dos outros) (FOUCAULT, 2014a, p. 208). 
Esta seção se inicia com a explicação acima pelo fato de ela já adiantar pelo menos três questões inevitáveis, quando se pretende discutir a genealogia e a ética em Foucault.

Primeiro, é preciso considerar que o prefácio em questão fora escrito no início dos anos de 1980, quando Foucault já podia avaliar, em seu trabalho, os três eixos que constituíram suas preocupações em torno da relação entre os discursos e os modos de agir e de pensar, que permitiu identificar, definir e valorar os saberes, os poderes e os sujeitos na história do Ocidente. Em entrevista ocorrida em 1983, Foucault (2014b, p. 224), falando da interpretação genealógica, anuncia que os três eixos são possíveis para uma genealogia e que estiveram "presentes, mesmo de uma maneira um pouco confusa, na História da loucura. Eu estudei o eixo da verdade em $O$ nascimento da clínica e em $A$ arqueologia do saber. Desenvolvi o eixo do poder em Vigiar e punir e o eixo moral na História da sexualidade".

Os três eixos marcaram também a distinção de três fases da pesquisa foucaultiana: arqueológica, genealógica e ética. Essa divisão constitui o segundo aspecto a ser considerado, por se ligar tanto aos métodos construídos por Foucault, quanto aos deslocamentos que ele mesmo realiza no estudo dos três eixos. Os deslocamentos operados por ele não podem ser entendidos como uma ruptura que se dá entre a passagem de um método arqueológico para um genealógico, por exemplo, mas como uma ampliação do campo de investigação para analisar o saber no interior das relações de poder. Como o próprio Foucault explica em entrevista de 1977, ele chegou a uma genealogia para analisar os problemas da constituição de objetos, discursos e domínios, no interior de uma trama histórica e não os remetendo a um sujeito constituinte; para analisar a constituição do sujeito na trama histórica. Continuando a explicação, ele conclui que chamaria de genealogia "uma forma de história que dê conta da constituição dos saberes, dos discursos, dos domínios de objetos etc., sem ter de se referir a um sujeito" (FOUCAULT, 2014c, p. 20). Arqueologia e genealogia têm, portanto, em seus trabalhos um fundamento metodológico comum, o sujeito não constituinte.

Em A arqueologia do saber, obra de 1969, o foco de estudo é colocado sobre os próprios discursos, enquanto práticas que obedecem a um jogo de regras, enquanto monumento que tem sua existência própria, não sendo signo de outra coisa, e indiferentes à instância de um sujeito fundador. A descrição arqueológica dos discursos procura revelar

[...] as práticas discursivas na medida em que dão lugar a um saber, e em que esse saber assume o status e o papel de ciência [...], [para] fazer aparecer [...] todo o jogo das diferenças, das relações, dos desvios, das defasagens, das independências, das autonomias, e a maneira pela qual se articulam entre si suas historicidades (FOUCAULT, 1995, p. 216). 
No final do último capítulo de A Arqueologia do saber, Foucault já sinalizava a ampliação de sua descrição arqueológica, colocando para si a pergunta sobre a possibilidade de a arqueologia interrogar outras experiências além da história das ciências. Ele responde que imagina de "bom grado [...] arqueologias que se desenvolveriam em direções diferentes" (FOUCAULT, 1995, p. 218) e considera a descrição arqueológica da sexualidade. Prenunciando essa tentativa, projeta a possibilidade de fazer uma análise em que

[...] ao invés de estudar o comportamento sexual dos homens em uma dada época [...], perguntaríamos se, nessas condutas, assim como nessas representações, toda uma prática discursiva não se encontrava inserida; se a sexualidade, fora de qualquer orientação para um discurso científico, não é um conjunto de objetos de que se pode falar (ou de que é proibido falar), um campo de enunciações possíveis [...] (FOUCAULT, 1995, p. 219).

A genealogia do poder já aparece aqui anunciada na investigação arqueológica, quando ele afirma que se "tal arqueologia fosse bem sucedida em sua tarefa, mostraria como as proibições, as exclusões, os limites, as valorizações, as liberdades, as transgressões da sexualidade, todas as suas manifestações, verbais ou não, estão ligadas a uma prática discursiva determinada" (FOUCAULT, 1995, p. 219). Nesse mesmo exercício de projeção de pesquisa, o filósofo ainda antecipa a genealogia da ética, ao considerar que "tal análise seria feita, assim, não na direção de episteme, mas no sentido do que se poderia chamar ética" (FOUCAULT, 1995, p. 219). Já havia nessa época, portanto, amarrado alguns deslocamentos que faria.

A terceira discussão, imprescindível, quando se trata de compreender o percurso analítico de Michel Foucault, liga-se à questão dos comportamentos dos homens como base e propósito da constituição dos conhecimentos, das relações de poder e dos modos de relação do indivíduo consigo mesmo. Assim, a partir do início da década de 1970, com a publicação de Vigiar e Punir, Foucault propõe uma nova posição acerca dos saberes do homem, para problematizar as formas modernas do poder. Os deslocamentos vão sendo operados por ele para a investigação de novos temas e para a abordagem dos já estudados sob novas perspectivas. Como pontua Castro (2016, p. 98), os deslocamentos sempre existiram nos trabalhos de Foucault, mas "não são rupturas; são torções, movimentos em torno de um eixo". Segundo o estudioso de Foucault, o eixo não se encontra representado pelo saber ou pelo poder, ou, ainda, pelo sujeito, mas pela forma como estes se relacionam.

Se em Vigiar e Punir, vai pensar nos saberes da disciplina, nos dispositivos individualizantes do poder, em 1978, com o curso Segurança, Território, População, vai 
analisar os comportamentos e experiências do homem como "o resultado e a condição dos dispositivos biopolíticos" (CASTRO, 2016, p. 95). O homem passa a ser elemento da população, que é objeto dos mecanismos biopolíticos de segurança. Como o próprio Foucault (2008, p. 62) esclarece: “a segurança, ao contrário da lei que trabalha no imaginário e da disciplina que trabalha no complementar da realidade, vai procurar trabalhar na realidade, fazendo os elementos da realidade atuarem uns em relação aos outros, graças e através de toda urna série de análises e de disposições específicas”. Com a ideia de população, configura-se um conjunto de elementos que pertencem ao regime geral dos seres vivos, mas que também possuem uma exterioridade corporal para ser transformada conforme cálculos e estimativas, mesmo que de forma autoritária. A população é, também, o público que, conforme Foucault (2008, p. 98), é uma noção capital, pois “é a população considerada do ponto de vista das suas opiniões, das suas maneiras de fazer, dos seus comportamentos, dos seus hábitos, dos seus temores, das suas exigências, é aquilo sobre o que se age por meio da educação, das campanhas, dos convencimentos". A partir desses estudos, que se darão nos cursos de 1978 e 1979, Segurança, Território, População e $O$ nascimento da biopolítica, respectivamente, Foucault vai ser conduzido a uma reelaboração da questão do homem e da subjetividade.

Outro deslocamento de eixo será anunciado por Foucault em 1980, e, talvez esse tenha sido o último e o que norteou os seus trabalhos até 1984: os livros História da sexualidade 2 e 3, e os cursos ministrados naquele ano e nos anos subsequentes até 1984, com A coragem da verdade. Na primeira aula do curso de 1980, Do governo dos vivos, Foucault declara que os temas de que ia tratar naquele ano o conduziram a elaborar um pouco mais a noção de governo dos homens pela verdade, noção já apresentada em Segurança, Território, População e $O$ nascimento da biopolítica. Ele explica que "“elaborar essa noção"” (FOUCAULT, 2014d, p. 12, destaque do autor) requer que as coisas sejam deslocadas "relativamente ao tema já batido e rebatido do saber-poder" (FOUCAULT, 2014d, p. 12). Requer um deslocamento da noção de saber-poder para a noção de governo pela verdade para tratar de temas como a relação entre o governo dos homens e a manifestação da verdade na forma da subjetividade.

$\mathrm{Na}$ introdução de História da sexualidade 2, explica que precisou fazer um deslocamento teórico das noções de saber (em que investigava as formas de práticas discursivas que o articulavam); poder (em que interrogava sobre as múltiplas relações, as estratégias e técnicas que articulavam o exercício dos poderes); e sujeito (em que empreendia o estudo das formas de relação consigo por meio das quais o indivíduo se constitui e se reconhece como sujeito) para "estudar os jogos de verdade na relação de si para si e a constituição de si mesmo como sujeito, tomando como espaço de referência e campo de 
investigação aquilo que poderia chamar-se 'história do homem de desejo"” (FOUCAULT, 1984, p. 11).

Considerando os deslocamentos efetuados por Foucault, principalmente, no que se convencionou chamar de "último Foucault", observa-se, também, a partir de 1980, uma investida do pesquisador-filósofo nas práticas do mundo antigo grego e romano para realizar o seu projeto sobre o governo e as práticas do dizer-a-verdade sobre si mesmo. Em seu último curso, ele revela que "a articulação entre os modos de veridicção, as técnicas de governamentalidade e as práticas de si é, no fundo, o que sempre procurei fazer" (FOUCAULT, 2011, p. 9). Como bem pontua Kraemer (2016), tanto na arqueologia, quanto na genealogia e também na ética, a questão a respeito da constituição da subjetividade, de como nos tornamos o que somos, é ponto central na perspectiva de Foucault. Em seus últimos trabalhos, Foucault vai "pensar o presente, não como determinado, mas como possibilidade de abertura para o ainda não presente [...] [se ocupar], prioritariamente, da atuação do sujeito, ou seja, do modo como cada um pode agir sobre si, sobre as verdades e as formas de poder que o atravessam" (KRAEMER, 2016, p. 68-69).

Essa articulação será a base para as discussões pretendidas nas partes seguintes deste texto, para tentar, de forma sintética, mostrar como o discurso e as práticas de si constituíram o centro das preocupações de Foucault em seu trabalho com a ontologia histórica da ética, em que buscou, nos períodos helênico e greco-romano, uma maneira específica e singular de problematizar as relações do homem com a moral e de fazer um diagnóstico de seus comportamentos e ações no presente. Essa divisão em partes responde apenas a uma proposta de organização, sendo necessário, portanto, esclarecer que discursos e práticas de si constituem tanto o fazer quanto o dizer dos sujeitos.

\section{A ética passa pelos discursos}

Castro (2016, p. 96), comentando sobre a necessidade do terceiro deslocamento nos trabalhos de Foucault após o ciclo biopolítico, afirma que este deslocamento incidirá sobre a questão da linguagem, quando precisará se dedicar ao "modo como o acontecimento da enunciação pode não simplesmente modificar, mas também construir o ser do sujeito do enunciado". A preocupação de Foucault se voltará, então, para os modos de veridicção (não mais o saber), as técnicas de governamentalidade (não mais o poder) e as práticas de si (não mais o sujeito). Esse novo eixo será marcado pelas elaborações de Foucault acerca, 
principalmente, das noções de parresía e cuidado de si. Nesta seção, a questão do discurso ganhará espaço no sentido de tentar acompanhar os movimentos de Foucault em torno da indagação a respeito de "quais efeitos tem sobre essa subjetividade a existência de um discurso que pretende dizer a verdade a respeito dela" (FOUCAULT, 2016, p. 12).

No curso Subjetividade e verdade, de 1981, Foucault (2016, p. 13), sobre tal indagação, coloca a questão de como a relação com nós mesmos e com os outros "se vê afetada, modificada, transformada, estruturada pela existência desse discurso verdadeiro e dos efeitos que ele induz, pelas obrigações que impõe e pelas promessas que sugere ou formula". Com essa questão, ele inicia a problematização em torno da relação subjetividade e verdade e expõe sua concepção que considera a subjetividade como o que se constitui e transforma na relação que tem com sua própria verdade; a verdade, como um sistema de obrigações, indiferente ao que em determinado momento seja considerado verdadeiro e não o seja em outro - não se trata da verdade como conteúdo de conhecimento. Após essas advertências, Foucault ressalta que o objetivo das análises daquele ano é o de "mostrar de que modo as subjetividades como experiências de si e dos outros se constituem através das ligações do que poderíamos chamar de veridicções" (FOUCAULT, 2016, p. 14).

Para tratar das formas de veridicção, Foucault coloca o problema a propósito da sexualidade e dos aphrodísia dos gregos antigos. Os aphrodisía são o próprio foco da análise, por se tratar de um conjunto de práticas, que constituiu o campo de cuidado moral e definiu a substância ética da cultura grega antiga, e se distinguir de duas outras experiências: a cristã da carne e a da moderna da sexualidade. A análise de Foucault (2016, p. 70) parte da "percepção ética própria da experiência grega dos aphrodísia", que é ordenada por certos princípios que entrelaçam a substância ética de conduta do indivíduo aos atos ligados ao prazer e ao desejo. O uso dos aphrodísia devia obedecer às condições impostas pela necessidade, pelo momento oportuno e pelo status social, para não anular o prazer e o desejo. Foucault (2016) destaca os elementos de conduta necessários para o uso dos aphrodísia: haver uma verdadeira tecnologia do si, que diz respeito ao outro da atividade sexual, como forma de ter acesso ao status de sujeito; a obrigação de dizer a verdade, transmitir a verdade ao outro. Contudo, não se tratava de fornecer um modelo de comportamento a todo mundo, mas de ser mais inventivo com relação ao prazer e não aos interditos (FOUCAULT, 2014b).

O problema da veridicção será colocado, assim, em relação aos aphrodísia que, constituído de uma mistura de atos e prazeres que os gregos colocavam como parte de sua experiência, vão ser aprisionados em determinado jogo de verdade, ocasionando a existência de uma série de discursos e remanejamentos na experiência sexual (FOUCAULT, 2016, p. 
203). Isso se dará nos séculos I e II de nossa era com as regras de conduta propostas pelos estoicos, um código de conduta sexual, conforme Foucault (2016), que será “organizado em torno do casamento, que se torna o lugar exclusivo no qual a conduta sexual é autorizada". Com a análise que fará acerca da codificação da ética sexual dessa época, Foucault vai afirmar que o cristianismo herdou um sistema que já estava formado e estabelecido por um arcabouço codificador que determinava o que era permitido e proibido. Essa codificação traz como "armas e bagagem" (FOUCAULT, 2016, p. 206), que serão passadas ao cristianismo, o discurso de acompanhamento, pois o núcleo codificador, o casamento e a procriação, continua a ser o mesmo da Grécia clássica no período greco-romano, mas o discurso de acompanhamento não. Esse discurso também permite captar a forma de uma experiência: "subjetividade, verdade e codificação das condutas: é isso que aparece, quando não simplesmente olhamos o fio condutor da codificação e de suas transformações, mas quando levamos em conta, com o arcabouço de codificações, o discurso que o acompanha" (FOUCAULT, 2016, p. 207).

Assim, ele analisa esse discurso como um discurso em excesso que tenta reproduzir uma prática real anterior e estabelecer a verdade para aquilo que já existia nos comportamentos e que vai constituir um jogo de veridicção, marcado por explicações que oscilam entre a teoria da representação do real, a denegação ideológica e a racionalização. Gros (2016, p. 284) chama a atenção para o fato de a exposição sobre as relações entre o discurso verdadeiro e a realidade ter sido a mais longa na história dos cursos de Foucault no Collège de France, dada a "sua recusa de encontrar no real a razão de ser do discurso que diz a verdade sobre esse real". Foucault pontua tanto a inutilidade dos jogos de veridicção, pela espessa profusão de saberes que não garante o acesso ao real, quanto a sua eficiência, visto que muitos têm efeitos de realidade ou, melhor, de subjetivação. Os discursos são procedimentos de constituição de subjetividade; "não são ideologias que procuram mascarar um código, tampouco são uma racionalização de um código [...]: são procedimentos de subjetivação de um código" (FOUCAULT, 2016, p. 228).

Os aphrodísia dos gregos, portanto, são uma atividade, uma série de atos nos quais o indivíduo tinha relação com os outros, mas com a tecnologia de regulação da filosofia grega e romana dos séculos I e II, eles não serão mais uma classe de atos, mas vão apresentar-se como um relacionamento permanente de si mesmo com si mesmo. O indivíduo passa a tomar a atividade sexual como objeto de controle, de observação permanente que garantirá a clivagem, conforme Foucault (2016, p. 257), "entre o sexo-atividade e o sexo-status", que será tratado na próxima seção. Não é mais central o indivíduo medir ele mesmo sua própria 
atividade, mas tornar-se objeto para si mesmo como forma de garantir essa separação e esse controle.

Em O governo de si e dos outros, Foucault (2010) afirma que um discurso que pretende dizer a verdade não deve ser analisado com o critério do que seria uma história dos conhecimentos que possibilitasse determinar se eles dizem ou não a verdade. Sendo o discurso de verdade uma prática, e a verdade só acessada por meio de jogos de veridicção, a ontologia do discurso de verdade seria uma ficção, mostrando que a história do pensamento tem de ser a história das invenções singulares, relacionada a um princípio de liberdade, não como um direito de ser, mas como uma capacidade de fazer. Ele afirma isso a propósito da distinção entre parresía e retórica, temas trabalhados após sua incursão na problematização dos princípios da pragmática. A parresía, explica Foucault (2010, p. 64), "é uma maneira de se vincular a si mesmo no enunciado da verdade, de vincular livremente a si mesmo e na forma de um ato corajoso [...] é a ética do dizer a verdade, em seu ato arriscado e livre". Arriscado, na medida em que os sujeitos que empreendem dizer-a-verdade voluntariamente aceitam, também de forma voluntária, que esse dizer a verdade pode lhe custar a própria existência, que seu ato de enunciação tem efeitos de retorno. Livre, porque a parresía estabelece um vínculo entre liberdade e verdade, já que a coragem de dizer-a-verdade seja um exercício superior de liberdade.

Para analisar esse ato corajoso e livre de dizer a verdade, no início do referido curso, Foucault (2010) o confronta com a noção de enunciado performativo da Pragmática da linguagem. Demonstra que os postulados da pragmática definem o enunciado performativo conforme os elementos dados da situação (que pressupõem um efeito já conhecido, regulado e codificado à enunciação) e o estatuto do sujeito (não importando que haja uma relação pessoal entre quem enuncia e o próprio enunciado, importa realizar o enunciado pelo estatuto que carrega). Na parresía, a irrupção do discurso verdadeiro abre a situação e torna possível efeitos que não são conhecidos, o sujeito compromete o que pensa no que ele diz e assume o risco pelos efeitos que podem ser produzidos e firma o pacto parresiástico: "sou aquele que disse isso" (FOUCAULT, 2010, p. 62). A diferença entre um ato performativo e um ato parresiástico se resume assim nas palavras de Foucault (2010, p. 63):

Enquanto o enunciado performativo define um jogo determinado no qual o estatuto de quem fala e a situação na qual se encontra determinam exatamente o que ele pode e o que ele deve dizer; só há parresía quando há liberdade na enunciação da verdade, liberdade do ato pelo qual o sujeito diz a verdade, e liberdade também desse pacto pelo qual o sujeito que fala se liga ao enunciado e à enunciação da verdade. 
Ao se ligar a seu dizer verdadeiro, o sujeito afirma, modifica, determina, explicita seu modo de ser na medida em que fala, não sendo, portanto, algo de que trataria a pragmática, visto que, em sua proposta de análise, o importante seja saber quais elementos da situação ou do estatuto do sujeito modificam ou afetam o sentido ou valor do enunciado. Diante dessas diferenças, Foucault (2010) propõe uma dramática do discurso para revelar o contrato do sujeito falante consigo mesmo no ato do dizer-a-verdade, sujeito que se liga à verdade de maneira singular e não ritualizada ou previsível. A parresía seria a qualificação ética do sujeito falante na sua relação com seus interlocutores. E "a história crítica da verdade está relacionada à produção de enunciações [pois] ao elaborar discursos, o sujeito problematiza suas práticas e seu modo de ser no mundo" (CANDIOTTO, 2013b, p. 152). Por isso, uma dramática do discurso verdadeiro para dar conta da análise do como o próprio acontecimento da enunciação pode afetar o ser do enunciador. Foucault (2006) considera que uma nova ética da relação verbal com o outro se desenvolve com a noção de parresía.

Para levar adiante o seu projeto de estudar o dizer-a-verdade no contexto do governo de si e dos outros, Foucault (2010) vai mostrar as modificações por que passa a noção de parresía antiga, nos primeiros séculos de nossa era, e confrontar a parresía a duas práticas, sendo uma moral, a lisonja, e outra técnica, a retórica.

Quanto às modificações, a parresía ganha uma função necessária e universal; passa a ter certa ambiguidade, ao dar a todos que quiserem a possibilidade de falar, não importando se há simulação; tem seu alvo deslocado, não será mais um conselho dado à cidade, mas uma atividade que se dirige à alma dos que devem governar; passa a ser exercida em qualquer regime, colocando-se como problema a distinção entre o que é verdadeiro e o que é ilusório. É assim que Foucault (2010) demonstra a clivagem construída entre a retórica e a filosofia. Anteriormente, no curso A hermenêutica do sujeito, Foucault já havia colocado essa diferença:

A retórica é o inventário e a análise dos meios pelos quais pode-se agir sobre os outros mediante o discurso. A filosofia é o conjunto de princípios e de práticas que se pode ter à própria disposição ou colocar à disposição dos outros, para tomar cuidados, como convém, de si mesmo ou dos outros" (FOUCAULT, 2006, p. 167).

A parresía se define também em oposição à retórica, posto que esta porta um discurso indiferente à verdade pela possibilidade de dizer a favor ou contra, o justo ou injusto. $\mathrm{O}$ discurso retórico é marcado pela preocupação do efeito que poderá produzir na alma de quem 
escuta, pelo objetivo de persuadir os outros. A parresía filosófica se identifica não só com um modo de discurso, mas "com a própria vida" (FOUCAULT, 2010, p. 296), caracteriza-se pelo fato de não ter outra forma senão a de ser a mais próxima possível do real a que se refere. Foucault, com base em análise de textos de Sócrates, ressalta que a retórica é um instrumento que possibilita o falante jogar, no sistema igualitário, o jogo dos estatutos privilegiados; o "instrumento para tornar novamente inigualitária uma sociedade à qual se procurou impor uma estrutura igualitária mediante leis democráticas" (FOUCAULT, 2010, p. 334).

A retórica é, portanto, um aparato técnico que pressupõe uma prática de discurso jogada no sentido de convencer uma maioria, prevalecer sobre os rivais e se tornar o primeiro. A parresía é, também, uma prática contrária à adulação ou lisonja, a sua inimiga moral, visto que "lisonjear é pegar no ouvinte o que ele já pensa, formulá-lo por conta própria como meu próprio discurso pessoal, e restituí-lo ao ouvinte, que fica com isso tanto mais convencido e tanto mais facilmente seduzido por ser o que ele diz" (FOUCAULT, 2010, p. 336). O lisonjeador se sente em posição inferior, mas quer parecer superior. Se transmitisse um discurso verdadeiro ao outro, este, interiorizando este discurso verdadeiro, subjetivando-o, poderia se dispensar da relação com o outro e ter sua independência. Desse modo, "a verdade que na parrhesía passa de um ao outro sela, assegura, garante a autonomia do outro, daquele que recebeu a palavra relativamente a quem a pronunciou (FOUCAULT, 2006, p. 458).

A questão da autonomia é problematizada também por Foucault (2010), comprovando o modo como ele assume a ética, sem ligá-la a prescrições de comportamento, valor ou verdade aos outros, por perceber "a impossibilidade de fundamentar qualquer conteúdo objetivo sem cair no dogmatismo" (KRAEMER, 2016, p. 71). Essa problematização se dá na esteira da Crítica kantiana em que a questão é colocada em relação "a saída do homem da sua menoridade, pela qual ele próprio é responsável” (FOUCAULT, 2010, p. 25). Foucault (2010) analisa que o estado de menoridade é caracterizado na relação governo de si, governo dos outros, em que a superimposição da direção dos outros ao uso que poderíamos e deveríamos fazer do nosso próprio entendimento não se deve à violência de uma autoridade, mas simplesmente a nós mesmos, comprovando um déficit na relação de autonomia consigo mesmo.

Em A coragem da verdade, Foucault (2011) discute a parresía segundo as práticas da filosofia cínica que a levaram ao extremo para ligar diretamente modo de vida e dizer-averdade. O cinismo, conforme mostra Foucault (2011), não se contenta com fazer se corresponderem numa harmonia um tipo de discurso e uma vida conforme apenas aos princípios enunciados no discurso. O cínico faz da forma da existência uma condição 
essencial para o dizer-a-verdade, um escândalo vivo da verdade Foucault situa, então, o cinismo na história da coragem da verdade. Rompendo com os ideais platônicos da vida feliz e abençoada, o cínico transforma valores metafísicos já aceitos para viver uma vida verdadeira, uma vida outra, não dissimulada, independente e soberana. Coloca a vida em risco para dizer e viver a verdade, como forma de defender a ideia da verdade não dissimulada, de uma vida sempre pautada pela possibilidade de tornar-se outro. Foucault (2011) revela que lhe parece que há um esboço, através do cinismo, da matriz do que foi uma vida devotada à verdade e à veridicção, à manifestação pelo discurso da verdade. A prática da verdade cínica toma por objetivo

[...] mostrar que o mundo só poderá alcançar sua verdade, só poderá se transfigurar e se tornar outro para alcançar o que ele é em sua verdade à custa de uma mudança, de uma alteração completa na relação que temos conosco. E é nesse retorno de si a si, é nesse cuidado de si que se encontra o princípio da passagem para esse mundo outro prometido pelo cinismo (FOUCAULT, 2011, p. 278).

\section{As práticas de si como forma de constituição ética}

As práticas de si, de acordo com Foucault (2004a), tiveram, na antiguidade grega e romana, uma importância e uma autonomia muito maiores do que tiveram a seguir, quando foram confiscadas pelas instituições religiosas, pedagógicas, médicas. Assim, o estudo das formas de experiência pode ser feito, conforme o autor em outro texto (2014a), a partir de uma análise das 'práticas' discursivas ou não, se se designam por elas os diferentes sistemas de ação, enquanto são habilitados pelo pensamento entendido como a própria forma da ação que implica o jogo do verdadeiro e do falso, a aceitação ou a recusa da regra, a relação consigo mesmo e com os outros. Para ele, as técnicas de governo implicam a relação de si consigo mesmo e permitem pensar sobre o "conjunto das práticas pelas quais é possível constituir, definir, organizar, instrumentalizar as estratégias que os indivíduos, em sua liberdade, podem ter uns em relação aos outros", ou seja, "o que constitui a própria matéria da ética" (FOUCAULT, 2004, p. 286).

Quanto à questão da atitude do indivíduo ante à regra, é importante lembrar aqui a mudança ocorrida na percepção ética dos aphrodisía pelos gregos antigos, em que constituíam uma série de atos nos quais o indivíduo tinha relação com os outros, enfatizando a importância do campo social e o isomorfismo sociossexual, para uma percepção dada pelo novo código de conduta no período greco-romano, em que "a valorização das relações sexuais 
não podem mais ser feita de acordo com a grade geral das relações sociais" (FOUCAULT, 2016, p. 231). Os estoicos radicalizam o código, separando o sexo-atividade do sexo-status. A análise da fidelidade no casamento permite Foucault (2016) observar que o homem será situado, então, no ponto de intersecção de dois sistemas de relacionamento, em que sua virilidade vai ser o dever de ter relações sexuais com a esposa (sexo-atividade) e, no campo social, vai ser também um macho, mas com identificação não mais ligada ao exercício da atividade sexual, mas ao fato de ele ter na sociedade um status de homem que exclui o exercício de sua atividade. Talvez esteja aí a emergência das ideias de "armário" e família patriarcal da atualidade, para as quais o que interessa na sociedade, no lado de fora da intimidade, é a aparência do status de macho. Talvez esteja também o lado oposto do cinismo com o incentivo à hipocrisia. Foucault (2016, p. 239) considera que "é essa transformação de si para habitar um código, para aplicá-lo no interior de um sistema de valores, que era o principal objeto" e objetivos dessas novas artes de viver.

Nesse sentido, Foucault (2016, p. 268) conclui que “a história do 'cuidado' e das 'técnicas' de si seria uma maneira de fazer a história da subjetividade [...] através da implantação e das transformações, em nossa cultura, das relações com si mesmo, com seu arcabouço técnico e seus efeitos de saber". Assim, "se poderia retomar sob outro aspecto a questão da governamentalidade: o governo de si por si em sua articulação com as relações com outrem", considerando as prescrições de modos de vida, os aconselhamentos, os novos códigos que dirigem a vida hoje.

Nesta seção, a noção de cuidado de si é priorizada por se tratar de uma técnica que, ao mesmo tempo em que elabora experiências, também as transforma. Foucault (2004a) demonstra que o cuidado de si é ético em si mesmo e implica a arte de governar, a relação com os outros, desde que não se sobreponha ao cuidado de si mesmo. Também, "os gregos problematizavam efetivamente sua liberdade e a liberdade do indivíduo como um problema ético" (FOUCAULT, 2004a, p. 270), pois o ethos era a maneira de ser e de se conduzir, um modo de ser e de fazer do sujeito, visível para os outros. Na ordem da sexualidade, conforme Foucault (2004a), significava que, liberando seu desejo, o sujeito saberia como se conduzir eticamente nas relações de prazer com os outros, o que sofre transformação no sistema estoico dos séculos I e II, posto que o sujeito neste sistema deveria ter domínio sobre seu desejo e mesmo impedi-lo e não desejar: "a relação consigo torna-se condição prévia para se ter direito ao domínio sobre os outros" (FOUCAULT, 2016, p. 238).

Nesse sentido, à pergunta colocada por Foucault (1984) em relação a como identificar a razão de ser da preocupação com a conduta sexual na cultura antiga, quando ela não era 
proibida ou reprimida, e a razão pela qual os cidadãos livres dos séculos I e II sujeitaram-se à diminuição do ato sexual, à fidelidade conjugal e à abstinência do amor masculino, ele vai encontrar respostas nos códigos da relação consigo. Não bastava ser homem livre, era preciso mostrar na prática que ele merecia tal status. Com esse intuito, era imprescindível fazer bom uso dos prazeres mediante uma liberdade estilizada. Candiotto (2013a) ressalta que, certamente, o ponto mais importante nos dois últimos volumes de História da sexualidade, que se dá com a problematização da conduta sexual, seja a análise histórica das modalidades de relação de si para consigo, das diferentes maneiras pelas quais os sujeitos tomam alguma parte de si próprios como centro de preocupação ética.

O "ocupar-se de si", que era um dever do homem jovem, e o "conhece-te a ti mesmo" dos gregos antigos ganharão novos contornos no período helenístico e do Império, estendendo o cuidar-se de si para ser exercitado por toda a vida e tornando o "cuidado de si" um tema filosófico comum e universal. Dessa forma, "sob o signo do cuidado de si, os dois primeiros séculos da época imperial podem ser considerados como ápice de uma curva: uma espécie de idade de ouro na cultura de si” (FOUCAULT, 1985, p. 50). Também nessa época, “o cuidado de si é uma atividade das mais correntes e está na origem da rivalidade que opõe os retóricos aos que se voltam para si mesmos" (FOUCAULT, 2014e, p. 276).

O cuidado de si, comenta Foucault (2004), passou a ser denunciado, em nossas sociedades, como forma de amor a si mesmo, de egoísmo ou de interesse individual frente ao necessário sacrifício de si mesmo e ao interesse que se deve ter em relação aos outros buscados pelo cristianismo, que inseriu a salvação como uma forma de cuidar de si, mas realizada por meio da renúncia a si mesmo. Na modernidade, "infelizmente, esquecemos o cuidado de si” (FOUCAULT, 2004, p. 280), e o sujeito político, explica, passou a ser visto apenas como sujeito de direito, e o sujeito ético perdeu seu espaço. O conhecimento de si suplantou o cuidado de si, e o sujeito pensante "ganhou uma importância cada vez maior como primeira marca da teoria do saber [...] No mundo moderno, o conhecimento de si constitui o princípio fundamental" (FOUCAULT, 2014e, p. 270).

Em O governo de si e dos outros, a propósito das práticas de si na Antiguidade dos séculos I e II, Foucault (2010, p. 41) ilustra a importância da parresía nessas práticas, visto que "não se pode cuidar de si mesmo, se preocupar consigo mesmo sem ter relação com outro. E o papel desse outro é precisamente dizer a verdade [...] e dizê-la de uma certa forma que é precisamente a parresía".

Na filosofia cínica, o cuidado de si vem representado pelo exercício da soberania, que é manifestada na alegria de viver e na prática da verdade manifestada, num trabalho da 
verdade de si sobre si: “o cínico é [...] como a estátua visível da verdade. Despojado de todos esses vãos ornamentos, de tudo que seria de certo modo, para o corpo, o equivalente da retórica, mas ao mesmo tempo florescente, em plena saúde: o próprio ser do verdadeiro, tornado visível através do corpo" (FOUCAULT, 2011, p. 274).

\section{Para finalizar, por uma estética da existência}

Esta finalização é instigada pela perspectiva de este texto ter cumprido sua tarefa de realçar que qualquer análise do discurso não pode prescindir de uma ontologia da ética, como forma de problematizar e refletir sobre os acontecimentos discursivos do presente. Relacionando duas considerações de Foucault (2006) em A hermenêutica do sujeito e seu posicionamento crítico no texto "O que são as Luzes?" (2000a), é possível entrever a possibilidade de o indivíduo se constituir como um sujeito ético, mesmo estando sujeitado ao código moral e submetido às regras. A primeira das considerações é positiva no sentido da possibilidade de constituição de um sujeito autônomo. Foucault (2006, p. 385) explica que o problema que os antigos "colocam acerca das relações entre sujeito e prática consiste em saber em que medida o fato de conhecer a verdade, de dizer a verdade, de praticar e de exercer a verdade, pode permitir ao sujeito não somente agir como deve agir, mas ser como deve ser e como quer ser".

A outra consideração é sobre o presente e se mostra mais negativa, talvez até pessimista, quando Foucault assinala a ausência de significação de expressões muito corriqueiras hoje nos discursos, como retornar a si, liberar-se, ser você mesmo ou ser autêntico, e afirma não haver do que se orgulhar no trabalho de reconstituição da ética de si. E continua:

E é possível que nestes tantos empenhos para reconstituir uma ética do eu, nesta série de esforços mais ou menos estanques, fixados em si mesmos, neste movimento que hoje nos leva, ao mesmo tempo, a nos referir incessantemente a esta ética do eu, sem contudo jamais fornecer-lhe qualquer conteúdo, é possível suspeitar que haja uma certa impossibilidade de constituir hoje uma ética do eu, quando talvez seja esta uma tarefa urgente, fundamental, politicamente indispensável, se for verdade que, afinal, não há outro ponto, primeiro e último, de resistência ao poder político senão na relação de si para consigo (FOUCAULT, 2006, p. 306). 
No texto “O que são as luzes?”, pensando em dar um conteúdo mais positivo a uma crítica do que dizemos, pensamos e fazemos, através de uma ontologia de nós mesmos, Foucault (2000a, p. 347) trata da questão colocada por Kant, sobre os limites que o conhecimento deve abdicar de transpor, e propõe que a questão crítica deva se tornar positiva, e "no que nos é apresentado como universal, necessário, obrigatório, [procurarmos saber] qual é a parte do que é singular, contingente e fruto das imposições arbitrárias”. Arremata a questão afirmando que se trata "de transformar a crítica exercida sob a forma de limitação necessária em uma crítica prática sob a forma de ultrapassagem possível”. A crítica, assim, ao invés de se voltar às "estruturas formais de valor universal, fará a pesquisa histórica através dos acontecimentos que nos levaram a nos constituir e nos reconhecer como sujeitos do que fazemos, pensamos e dizemos". A crítica seria arqueológica em seu método e genealógica em sua finalidade, "no sentido de que ela não deduzirá da forma do que somos o que para nós é impossível fazer ou conhecer; mas deduzirá da contingência que nos fez ser o que somos a possibilidade de não mais ser, fazer ou pensar o que somos, fazemos ou pensamos (FOUCAULT, 2000a, p. 348).

Este artigo se encerra sob essa perspectiva e, por isso, propondo, ou melhor referendando, a estética da existência da antiguidade como possibilidade de resistências, de construção da autonomia e da saída da menoridade. Conforme Foucault (2004b), o sujeito, em meio às técnicas de sujeição, pode se constituir de maneira mais autônoma, como na antiguidade, por meio de práticas de liberação, de liberdade. Essas práticas se ligam a uma estética da existência, como forma de afirmar a liberdade e para dar à própria vida certa forma, na qual pode se reconhecer, ser reconhecido pelos outros e na qual se pode deixar lembranças de uma existência bela. Com o tema da verdadeira vida e da vida outra, em oposição à promessa de outra vida em outro mundo, os cínicos experimentaram, no corpo e nas atitudes, o exercício de uma estética da existência na própria experiência vivida, mostrando que a liberdade e a autonomia se conquistam pela descoberta de que há outras possibilidades de viver e de estar no mundo; possibilidades que o sujeito pode criar, inventar. Trata-se de alterar o valor da moeda, conforme o lema dos cínicos, substituindo a moeda falsa da opinião que temos de nós mesmos ou que os outros têm, para, assim, podermos "manipular nossa existência, $[\ldots]$ cuidar de nós mesmos como de uma coisa real, [...] ter em nossas mãos a moeda verdadeira da nossa existência verdadeira contando que nos conheçamos a nós mesmos" (FOUCAULT, 2011, p. 212).

As "artes da existência" (FOUCAULT, 2004) dos antigos são práticas voluntárias que ensinam o cuidado ético, ou seja, a possibilidade de o indivíduo se relacionar com as 
interdições, problematizá-las, determinar para si regras de conduta, modificar-se em seu ser singular e transformar sua vida numa obra de valor estético conforme certos critérios de estilos.

\section{Referências}

CANDIOTTO, C. A genealogia da ética de Michel Foucault. Educação e Filosofia. Uberlândia, v. 27, n. 53, p. 217-234, jan./jun. 2013. ISSN 0102-6801. DOI: https://doi.org/10.14393/REVEDFIL.issn.0102-6801.v27n53a2013-p217a234

CASTRO, E. Michel Foucault: a verdade do homem. In: MANSANO, S. R. V. (Org.). Michel Foucault: desdobramentos. Belo Horizonte: Autêntica Ed., 2016

FOUCAULT, M. História da sexualidade 2: o uso dos prazeres. Rio de Janeiro, Ed. Graal, 1984.

FOUCAULT, M. História da sexualidade 3: o cuidado de si. Rio de Janeiro, Ed. Graal, 1985.

FOUCAULT, M. A arqueologia do saber. Rio de Janeiro: Forense Universitária, 1995.

FOUCAULT, M. O que são as luzes? In: FOUCAULT, M. Ditos e escritos II - Arqueologia das ciências e história dos sistemas de pensamento. Rio de Janeiro: Forense Universitária, 2000a.

FOUCAULT, M. Nietzsche, a genealogia, a História. In: FOUCAULT, M. Ditos e escritos II - Arqueologia das ciências e história dos sistemas de pensamento. Rio de Janeiro: Forense Universitária, 2000b.

FOUCAULT, M. A ética do cuidado de si como prática da liberdade. In: FOUCAULT, M. Ditos e escritos V - Ética, sexualidade, política. Rio de Janeiro: Forense Universitária, 2004a.

FOUCAULT, M. Uma estética da existência. In: FOUCAULT, M. Ditos e escritos V - Ética, sexualidade, política. Rio de Janeiro: Forense Universitária, 2004b.

FOUCAULT, M. A hermenêutica do sujeito. São Paulo: Martins Fontes, 2006.

FOUCAULT, M. Segurança, território, população. São Paulo: Martins Fontes, 2008.

FOUCAULT, M. O governo de si e dos outros: curso no Collège de France (1982-1983). São Paulo: WMF Martins Fontes, 2010.

FOUCAULT, M. A coragem da verdade: o governo de si e dos outros II: curso no Collège de France (1983-1984). São Paulo: WMF Martins Fontes, 2011. 
FOUCAULT, M. Prefácio à História da sexualidade. In: FOUCAULT, M. Ditos e escritos IX - Genealogia da ética, subjetividade e sexualidade. Rio de Janeiro: Forense Universitária, 2014a.

FOUCAULT, M. Sobre a genealogia da ética. In: FOUCAULT, M. Ditos e escritos IX Genealogia da ética, subjetividade e sexualidade. Rio de Janeiro: Forense Universitária, 2014b.

FOUCAULT, M. Entrevista com Michel Foucault. In: FOUCAULT, M. Ditos e escritos IX Genealogia da ética, subjetividade e sexualidade. Rio de Janeiro: Forense Universitária, 2014c.

FOUCAULT, M. Do governo dos vivos: curso no Collège de France (1979-1980). São Paulo: WMF Martins Fontes, 2014d.

FOUCAULT, M. As técnicas de si. In: FOUCAULT, M. Ditos e escritos IX - Genealogia da ética, subjetividade e sexualidade. Rio de Janeiro: Forense Universitária, 2014e.

FOUCAULT, M. Subjetividade e verdade: curso no Collège de France (1980-1981). São Paulo: WMF Martins Fontes, 2016.

GROS, F. Situação do curso. FOUCAULT, M. A hermenêutica do sujeito. São Paulo: Martins Fontes, 2006.

GROS, F. Situação do curso. In: FOUCAULT, M. Subjetividade e verdade: curso no Collège de France (1980-1981). São Paulo: WMF Martins Fontes, 2016.

KRAEMER, C. A ontologia e a ética em Michel Foucault. In: RESENDE, H. (Org.). Michel Foucault: política: pensamento e ação. Belo Horizonte: Autêntica Ed., 2016.

Recebido em: 22 de maio de 2019

Aceito em: 21 de junho de 2019 